\title{
Analisis Perilaku dan Loyalitas Pelanggan ZAP Clinic
}

\author{
Claresta Dwi Pranindya, Berto Mulia Wibawa, dan Janti Gunawan \\ Departemen Manajemen Bisnis, Fakultas Bisnis dan Manajemen Teknologi, \\ Institut Teknologi Sepuluh Nopember (ITS) \\ e-mail: clarestadwi@gmail.com
}

\begin{abstract}
Abstrak-Industri kecantikan di Indonesia dalam beberapa tahun terakhir ini berkembang pesat, salah satunya dipicu oleh tren media online termasuk media sosial. Salah satu klinik kecantikan di Indonesia yaitu ZAP Clinic masih belum berhasil menjadi top of mind pelanggan, melihat persaingan klinik kecantikan di Indonesia yang semakin kompetitif. ZAP Clinic dapat memanfaatkan media sosial untuk membangun ekuitas merek yang kuat di benak konsumen dan mendapatkan respon yang baik dari konsumen. Selain itu, rendahnya engagement rate pada salah satu akun media sosial menjadi tantangan bagi ZAP untuk menciptakan konten yang sesuai dengan karakteristik pengikut media sosialnya. Penelitian ini bertujuan untuk mengetahui perilaku pelanggan sekaligus pengikut media sosial ZAP Clinic serta mengetahui tingkat loyalitas pelanggan ZAP Clinic. Pengumpulan data dilakukan menggunakan survei dengan menyebarkan kuesioner secara online kepada 210 sampel yang menjadi pelanggan ZAP Clinic dan mengikuti setidaknya salah satu media sosial ZAP Clinic. Selanjutnya data dianalisis menggunakan crosstab dan Customer Loyalty Index (CLI). Temuan yang didapat dari analisis CLI adalah pelanggan ZAP Clinic termasuk loyal. Terdapat beberapa implikasi manajerial yang dapat diterapkan oleh ZAP Clinic untuk meningkatkan ekuitas merek sehingga mendapatkan respon yang positif dari konsumen seperti membuat konten media sosial yang menarik dan up to date. Untuk mempertahankan loyalitas pelanggan, ZAP Clinic perlu menjaga kualitas layanannya dan memberikan beberapa program loyalitas.
\end{abstract}

Kata Kunci-CLI, Crosstab, Pemasaran Media Sosial, Respon Konsumen, ZAP Clinic.

\section{PENDAHULUAN}

$\mathrm{S}_{\mathrm{d}}^{\mathrm{e}}$ iring dengan berkembangnya jaman, industri kecantikan di dunia pun turut berkembang pesat, tak terkecuali di Indonesia. Kementerian Perindustrian Republik Indonesia (2017) menyatakan bahwa dalam 10 tahun terakhir, industri kecantikan dan perawatan pribadi di Indonesia bertumbuh sekitar 12 persen per tahun dengan nilai pasar mencapai $\mathrm{Rp}$ 33 triliun [1]. Hal tersebut menandakan bahwa masyarakat Indonesia semakin peduli untuk merawat kecantikan diri. Pertumbuhan industri kecantikan dipicu oleh tiga kategori besar yaitu tata rias sekitar 10 persen, perawatan kulit sekitar 32 persen, dan perawatan rambut sekitar 37 persen [2].

Berkembangnya industri kecantikan di Indonesia salah satunya ditandai oleh semakin banyak klinik kecantikan yang didirikan dengan menawarkan berbagai metode perawatan, dengan pertumbuhan sekitar 15 persen dalam empat tahun terakhir [3]. Konsumen industri kecantikan di Indonesia rela mengeluarkan paling tidak 20 persen dari total uang belanja untuk membeli produk fashion dan perawatan kecantikan [4].

Tingginya indeks kepercayaan konsumen untuk melakukan pembelian serta didukung oleh meningkatnya kesadaran akan tren kecantikan dan perawatan diri melalui media internet dan media lainnya, telah menjadikan perawatan kecantikan sebagai gaya hidup masyarakat Indonesia. Tren media online termasuk media sosial turut memicu berkembangnya industri kecantikan di Indonesia, dimana sebagian besar wanita Indonesia mencari informasi mengenai kecantikan melalui Instagram dan YouTube [5] [4].

Salah satu perusahaan di bidang klinik kecantikan yang memanfaatkan media sosial sebagai alat komunikasi pemasarannya adalah ZAP Clinic. ZAP berhasil meraih cukup banyak pengikut di berbagai akun media sosialnya seperti Instagram, LINE@, Facebook, YouTube, dan Twitter berkat aktifnya ZAP dalam menggunakan media sosial untuk memasarkan layanannya.

Sejak tahun 2016, ZAP Clinic berhasil meraih Top Brand Award untuk kategori Jasa Hair Removal dengan top brand index (TBI) sebesar 34,8 persen pada tahun 2018 [6]. Namun ZAP Clinic belum berhasil mengalahkan para pesaingnya dalam Top Brand Award 2018 kategori klinik kecantikan atau perawatan kulit. Hal tersebut menandakan bahwa ZAP Clinic belum menjadi top of mind pelanggan klinik kecantikan, dimana pelanggan klinik kecantikan di Indonesia masih belum mudah mengenali merek ZAP, belum banyak yang menggunakan layanan ZAP, serta belum banyak pelanggan yang berkomitmen untuk menggunakan kembali layanan dari ZAP di masa mendatang. Sedangkan, ZAP Clinic menargetkan agar perawatan kulit menggunakan laser dan cahaya dari ZAP dapat menjadi top of mind pelanggan klinik kecantikan di Indonesia [7]. Selain itu, salah satu media sosial ZAP yaitu Instagram @zapcoid masih menunjukkan engagement rate yang rendah yaitu 0,22 persen, di bawah standar yaitu 3 persen untuk Instagram engagement calculator, Triberr.

Aktivitas pemasaran melalui media sosial dapat meningkatkan kesadaran merek dan menanamkan citra yang baik di antara pengguna media sosial [8]. Selain itu, beberapa ahli berpendapat bahwa semakin kuat ekuitas merek suatu merek, maka konsumen akan lebih memberikan respon yang positif dengan bentuk preferensi merek, kerelaan untuk membayar harga yang tinggi, serta loyalitas merek [9]. Maka dari itu, penelitian ini bertujuan untuk menganalisis perilaku pelanggan dalam melakukan perawatan kecantikan dan menggunakan media sosial ZAP Clinic untuk menyusun strategi pemasaran yang sesuai, serta menganalisis tingkat loyalitas pelanggan terhadap layanan yang ditawarkan ZAP Clinic untuk merekomendasikan strategi untuk mempertahankan dan meningkatkan loyalitas pelanggan. 


\section{II.LANDASAN TEORI}

\section{A. Pemasaran Media Sosial}

Pemasaran bertujuan untuk menarik pelanggan baru dengan menawarkan nilai yang unggul dan untuk menjaga pelanggan yang telah ada dengan menyampaikan nilai dan kepuasan [10]. Dengan peningkatan mobilitas dan konektivitas, sebagian besar bisnis saat ini dilakukan melalui jaringan digital yang menghubungkan orang dan perusahaan secara real time. Pertumbuhan penggunaan internet telah memunculkan sejumlah media sosial maupun komunitas digital lainnya. Media sosial merupakan sarana bagi konsumen untuk berbagai informasi teks, gambar, video, dan audio dengan satu sama lain dan dengan perusahaan dan sebaliknya.

Pemasaran media sosial adalah aktivitas media sosial yang berfungsi untuk memfasilitasi interaksi, berbagi informasi, menawarkan rekomendasi pembelian yang dipersonalisasi, dan mencipatakan word of mouth di antara pelanggan tentang produk dan layanan yang ada dan yang sedang tren [9]. Pemasaran menggunakan media sosial memiliki beberapa manfaat bagi perusahaan, yaitu diatrgetkan dan bersifat pribadi, bersifat interaktif, cepat dan tepat waktu, hemat biaya, dan kemampuan keterlibatan serta social sharing [10].

Pemasaran media sosial memiliki beberapa dimensi yaitu entertainment atau hiburan dalam media sosial merupakan hasil dari kesenangan yang didapatkan dari pengalaman menggunakan media sosial, interaksi menggambarkan pengguna yang berkontribusi pada platform media sosial terkait merek tertentu untuk bertemu dan berinteraksi dengan perusahaan maupun orang lain, trendiness merupakan penyediaan informasi terbaru terkait produk atau layanan yang ditawarkan, customization mengacu pada audiens yang dituju melalui pesan yang diunggah, dan Word of mouth (WOM) dalam media sosial didefinisikan sebagai interkasi antar konsumen secara online terkait dengan merek tertentu [9].

\section{B. Ekuitas Merek}

Ekuitas merek merupakan nilai tambah yang diberikan kepada produk dan layanan dan dapat tercermin dalam cara konsumen berpikir, merasa, dan bertindak sehubungan dengan merek tertentu [11]. Ekuitas merek terukir dalam memori konsumen sebagai nilai unik yang membedakan suatu merek dengan merek yang lain. Ekuitas merek yang kuat dapat memberikan keunggulan kompetitif bagi perusahaan, dimana perusahaan akan mendapatkan kesadaran dan loyalitas yang tinggi dari konsumen. Ekuitas merek terdiri dua dimensi yaitu kesadaran merek merupakan upaya konsumen untuk mengingat atau mengenali suatu merek dalam detail yang cukup untuk melakukan pembelian dan citra merek merupakan persepsi terkait suatu merek yang terbentuk dalam pikiran konsumen, dan merupakan kombinasi dari perasaan konsumen terhadap produk tertentu dan terkait faktor tidak langsung [12].

\section{C.Respon Konsumen}

Respon konsumen merupakan tanggapan yang diberikan konsumen terhadap aktivitas pemasaran suatu merek yang biasanya dipengaruhi aspek kognitif, rasional, dan emosional
[12]. Konsumen dapat mengekspresikan rasa bangga, bersemangat, atau percaya diri atas suatu merek. Respon konsumen sering menjadi tolak ukur apakah strategi pemasaran yang dilakukan berhasil atau tidak. Meskipun tanggapan konsumen mungkin berbeda-beda dipengaruhi oleh pikiran dan hati, yang terpenting adalah seberapa positif respon konsumen.

Respon konsumen dapat dilihat dari beberapa bentuk seperti preferensi merek yang menunjukkan bahwa konsumen cenderung memilih suatu merek dibandingkan merek lain berdasarkan apa yang mereka ketahui dan mereka rasakan terhadap merek tersebut [12], kesediaan untuk membayar harga yang tinggi menunjukkan jumlah yang bersedia dibayar pelanggan untuk merek pilihannya dibandingkan merek lain yang menawarkan manfaat yang sama, dimana hasilnya bisa tinggi atau rendah dan positif atau negatif bergantung pada merek yang dibandingkan [13], dan loyalitas merek menggambarkan kedekatan, komitmen, dan perasaan positif konsumen kepada suatu merek dan salah satunya berbentuk perilaku pembelian berulang yang menggambarkan keputusan konsumen untuk terus membeli merek yang sama secara sadar [14].

\section{METODE PENELITIAN}

\section{A. Desain Penelitian}

Metode penelitian yang digunakan dalam penelitian ini adalah deskriptif. Penelitian ini bersifat deskriptif karena penelitian dilakukan mendeskripsikan perilaku pelanggan sekaligus pengikut media sosial ZAP Clinic dalam menggunakan media sosial dan loyalitas pelanggan terhadap layanan yang diberikan ZAP Clinic.

Data pada penelitian ini dikumpulkan dengan menggunakan desain multipe cross-sectinal yang mana dua atau lebih sampel diambil dari populasi yang diteliti dan informasi dari masing-masing sampel diambil dalam satu waktu [15]. Penelitian ini menggunakan data primer sebagai data utama dan data sekunder sebagai pelengkap informasi untuk menunjang kualitas hasil penelitian ini.

\section{B. Sampel Penelitian}

Populasi dalam penelitian ini adalah pelanggan sekaligus pengikut media sosial ZAP Clinic. Sampel pada penelitian ini sebanyak 155 responden berdasarkan jumlah indikator variabel yang digunakan dalam penelitian sebanyak 31 dikalikan lima [16]. Kriteria responden dalam penelitian ini adalah wanita yang telah melakukan perawatan di ZAP Clinic setidaknya dalam tiga bulan terakhir dan telah mengikuti setidaknya salah satu media sosial ZAP Clinic dalam satu bulan terakhir.

\section{C.Pengumpulan Data}

Pada penelitian ini, penyebaran kuesioner kepada responden dilakukan sendiri oleh peneliti yang selanjutnya akan diisi langsung oleh responden (self-administered questionnaire) menggunakan kuesioner online (Google Form). Kuesioner disebarkan secara online karena keberadaan responden yang merupakan pengikut media sosial ZAP Clinic yaitu dengan mengunggah poster berisi link 
kuesioner pada media sosial peneliti dan mengirimkan direct message kepada pengikut media sosial ZAP Clinic.

\section{D.Metode Analisis Data}

Penelitian ini menggunakan dua metode analisis data yaitu crosstab dan Customer Loyalty Index (CLI).

\section{Crosstab}

Crosstab adalah teknik statistik yang menggambarkan dua atau lebih variabel secara bersamaan, yaitu dengan menglasifikasikan satu atau lebih variabel secara silang. Penelitian ini melakukan analisis crosstab dengan menyilangkan data dari responden berdasarkan demografi responden dan usage responden, kemudian dapat dianalisis mengenai bagaimana perilaku pelanggan dalam melakukan perawatan kecantikan dan menggunakan media sosial ZAP Clinic untuk menyusun strategi pemasaran yang sesuai. Berikut adalah berbagai variabel yang digunakan dalam analisis crosstab (Tabel 1).

Tabel 1. Analisis Crosstab

\begin{tabular}{ccll}
\hline \hline No & Variabel 1 & \multicolumn{1}{c}{ Variabel 2 } & \multicolumn{1}{c}{ Variabel 3 } \\
\hline Crosstab 1 & Usia & Pekerjaan & $\begin{array}{l}\text { Rata-rata } \\
\text { pengeluaran untuk } \\
\text { perawatan dalam } \\
\text { satu kali kunjungan }\end{array}$ \\
Crosstab 2 & $\begin{array}{l}\text { Rata-rata } \\
\text { pendapatan } \\
\text { per bulan }\end{array}$ & $\begin{array}{l}\text { Rata-rata } \\
\text { pengeluaran untuk } \\
\text { perawatan dalam } \\
\text { satu kali kunjungan }\end{array}$ & $\begin{array}{l}\text { Frekuensi perawatan } \\
\text { kecantikan dalam } \\
\text { tiga bulan }\end{array}$ \\
& Usia & $\begin{array}{l}\text { Jenis perawatan } \\
\text { kecantikan yang } \\
\text { paling digemari }\end{array}$ & $\begin{array}{l}\text { Frekuensi perawatan } \\
\text { kecantikan dalam } \\
\text { tiga bulan }\end{array}$ \\
Crosstab 3 & Waktu penggunaan & $\begin{array}{l}\text { Akun media sosial } \\
\text { ZAP yang paling } \\
\text { sering dikunjungi }\end{array}$ \\
& & Usia sosial & $\begin{array}{l}\text { Konten media sosial } \\
\text { CAP yang paling } \\
\text { digemari }\end{array}$ \\
& & Bentuk konten \\
Crosstab 5 5 & Usia & paling digemari & \\
& & &
\end{tabular}

\section{Customer Loyalty Index (CLI)}

Consumer Loyalty Index (CLI) merupakan metode penelitian untuk mengetahui seberapa besar tingkat loyalitas pelanggan terhadap suatu produk atau jasa. Penelitian ini menggunakan CLI untuk menganalisis tingkat loyalitas pelanggan ZAP Clinic. Berikut adalah rumus untuk mengetahui tingkat loyalitas pelanggan [17].

$$
\mathrm{CLI}=\frac{\sum_{i}^{n} 1 \text { (Willing Statement) } \times 100 \%}{N}
$$

etelah dilakukan perhitungan CLI, maka diperoleh hasil tingkat loyalitas pelanggan. Berikut adalah rentang skala hasil Customer Loyalty Index (CLI) (Tabel 2).

$$
\text { Tabel } 2 .
$$

Rentang Skala Customer Loyalty Index (CLI)

\begin{tabular}{ccc}
\hline \hline Rentang Skala & Persentase $(\%)$ & Interpretasi \\
\hline $0,91-1,00$ & $91-100$ & Sangat Loyal \\
$0,71-0,90$ & $71-90$ & Loyal \\
$0,51-0,70$ & $51-70$ & Cukup Loyal \\
$0,26-0,50$ & $26-50$ & Kurang Loyal \\
$0,00-0,25$ & $0-25$ & Tidak Loyal \\
\hline \hline
\end{tabular}

\section{ANALISIS DAN DISKUSI}

\section{A. Analisis Data dan Diskusi}

Dari penyebaran kuesioner secara online, diperoleh 277 responden yang mengisi kuesioner dan terdapat 210 responden yang memenuhi kriteria dan berhasil melewati tahap screening hingga menyelesaikan kuesioner. Setelah data diperoleh, data dianalisis menggunakan crosstab dan CLI.

\section{Analisis Crosstab}

Crosstab 1 - Analisis crosstab pertama memberikan informasi mengenai hubungan antara usia, pekerjaan, dan rata-rata pengeluaran untuk perawatan dalam satu kali kunjungan. Hasil analisis crosstab pertama menunjukkan bahwa mayoritas responden berusia 24 hingga 30 tahun merupakan wanita yang bekerja, terutama berprofesi sebagai pegawai swasta. Rata-rata responden yang berusia 24 hingga 30 tahun mengeluarkan $\mathrm{Rp} 500.001$ hingga $\mathrm{Rp} 1.000 .000$ untuk melakukan perawatan kecantikan dalam satu kali kunjungan di ZAP Clinic. Kelompok responden terbesar kedua adalah wanita berusia 19 hingga 23 tahun yang merupakan mahasiswa. Rata-rata responden dalam kelompok tersebut juga mengeluarkan $\mathrm{Rp} 500.001$ hingga $\mathrm{Rp} 1.000 .000$ untuk melakukan perawatan kecantikan. Responden yang berusia 31 hingga 35 tahun yang mayoritas merupakan wanita pekerja rela mengeluarkan Rp 1.000.001 hingga Rp 1.500.000 untuk menikmati layanan yang diberikan ZAP Clinic.

Hasil analisis crosstab juga menunjukkan rata-rata responden yang rela mengeluarkan $\mathrm{Rp} 1.500 .001$ hingga $\mathrm{Rp}$ 2.000.000 untuk melakukan perawatan kecantikan adalah responden yang berusia 31 hingga 35 tahun. Hal tersebut menunjukkan bahwa semakin matang usia wanita Indonesia, semakin tinggi pula biaya yang rela dikeluarkan untuk melakukan perawatan di klinik kecantikan. Namun, responden yang rela mengeluarkan biaya paling tinggi di atas Rp 2.000.000 tersebar pada kategori usia 19 hingga 30 tahun dan 41 hingga 50 tahun. Hal tersebut menggambarkan bahwa biaya yang dikeluarkan responden juga tergantung pada kompleksitas masalah yang dialami sehingga membutuhkan biaya perawatan yang tinggi atau jumlah perawatan kecantikan yang dijalani dalam satu kali kunjungan di ZAP Clinic.

Crosstab 2 - Analisis crosstab kedua memberikan informasi mengenai hubungan antara rata-rata pendapatan per bulan, rata-rata pengeluaran untuk perawatan dalam satu kali kunjungan, dan frekuensi perawatan kecantikan dalam tiga bulan. Hasil analisis crosstab menunjukkan bahwa mayoritas pelanggan ZAP Clinic melakukan perawatan kecantikan empat kali atau lebih dalam kurun waktu tiga bulan. Pelanggan yang melakukan perawatan kecantikan lebih dari empat kali dalam tiga bulan didominasi oleh yang memiliki rata-rata pendapatan $\mathrm{Rp} 5.000 .001$ hingga $\mathrm{Rp} 8.000 .000$ per bulannya. Hal tersebut menunjukkan bahwa pelanggan ZAP Clinic yang memiliki pendapatan di tingkat menengah lebih rutin melakukan perawatan kecantikan, sekiranya lebih dari satu kali dalam satu bulan. Selain itu, mayoritas pelanggan ZAP Clinic rela mengeluarkan $\mathrm{Rp} 500.001$ hingga $\mathrm{Rp}$ 1.000.000 untuk melakukan perawatan kecantikan dalam satu kali kunjungan, dimana pelanggan bisa saja melakukan lebih dari satu jenis perawatan kecantikan dalam satu kali kunjungan. Jumlah pengeluaran tersebut didominasi oleh 
pelanggan yang memiliki rata-rata pendapatan $\mathrm{Rp} 2.000 .001$ hingga Rp 8.000 .000 sebanyak 41 orang. Hal tersebut terjadi karena semakin meningkatnya ekonomi dan gaya hidup, semakin tinggi pula kesadaran wanita di Indonesia untuk menjaga kecantikannya dengan melakukan perawatan di klinik kecantikan. Selain itu, terdapat beberapa pelanggan yang rela mengeluarkan lebih dari $\mathrm{Rp} 2.000 .000$ untuk melakukan perawatan kecantikan dalam satu kali kunjungan yang didominasi oleh pelanggan yang memiliki rata-rata pendapatan lebih dari Rp 11.000.000 per bulan.

Frekuensi melakukan perawatan kecantikan tersebut mengindikasikan bahwa pelanggan ZAP Clinic memiliki rutinitas untuk melakukan perawatan kecantikan meskipun berbeda-beda, demi menjaga kesehatan dan kecantikan kulitnya. Perbedaan rutinitas tersebut terjadi karena beberapa faktor seperti tingkat ekonomi, gaya hidup, dan kebutuhan untuk merawat kecantikan yang berbeda-beda setiap individu. Dapat disimpulkan bahwa terdapat kecenderungan pelanggan rutin melakukan perawatan kecantikan dengan pengeluaran yang cukup tinggi.

Crosstab 3- Analisis crosstab ketiga memberikan informasi mengenai hubungan antara usia, jenis perawatan kecantikan yang paling digemari, dan frekuensi perawatan kecantikan dalam tiga bulan. Hasil analisis crosstab menunjukkan bahwa semua pelanggan ZAP Clinic dengan kategori usia mulai 19 tahun hingga 50 tahun menyukai jenis perawatan photo facial yaitu paket perawatan yang terdiri dari alma rejuvenation, face toning, dan oxy infusion. Perawatan photo facial paling digemari karena pelanggan bisa merasakan manfaat yang banyak dalam satu kali perawatan dengan harga yang lebih terjangkau dibandingkan membeli satuan. Namun, pelanggan yang menyukai perawatan photo facial didominasi oleh yang berusia 24 hingga 30 tahun. Hal tersebut menunjukkan bahwa kategori usia tersebut paling memerhatikan kesehatan dan kecantikan kulit wajahnya dibandingkan dengan anggota tubuh lain. Selain itu, hal tersebut terjadi karena wanita berusia 24 hingga 30 tahun memiliki berbagai masalah kulit yang dapat diselesaikan dengan photo facial, yaitu masalah jerawat dapat diatasi dengan alma rejuvenation, masalah kulit kusam diatasi dengan face toning, dan masalah kulit yang lelah dapat diatasi dengan oxy infusion mengingat kategori tersebut memiliki produktivitas yang tinggi. Mayoritas pelanggan yang menyukai perawatan photo facial rutin melakukan perawatan empat kali atau lebih dalam kurun waktu tiga bulan. Hal tersebut dilakukan pelanggan ZAP Clinic untuk lebih cepat mendapatkan hasil yang maksimal.

Jenis perawatan kedua yang paling digemari pelanggan ZAP Clinic adalah hair removal didominasi oleh pelanggan yang berusia 24 hingga 30 tahun. Hal tersebut menunjukkan bahwa semakin dewasa usia wanita di Indonesia, semakin tinggi pula kesadaran untuk merawat kecantikan tidak hanya untuk wajah, namun untuk menghilangkan rambut di wajah atau badan. Rata-rata pelanggan yang menyukai perawatan hair removal melakukan perawatan sebanyak tiga kali dalam tiga bulan, sesuai dengan anjuran untuk melakukannya minimal satu kali dalam satu bulan. Selain itu, terdapat annual membership untuk perawatan hair removal yang mengharuskan pelanggan untuk melakukan perawatan setiap bulan.

Crosstab 4 - Analisis crosstab keempat memberikan informasi mengenai hubungan antara usia, waktu penggunaan media sosial, dan akun media sosial ZAP yang paling sering dikunjungi. Hasil analisis crosstab keempat menunjukkan mayoritas responden paling sering mengunjungi akun media sosial Instagram ZAP Clinic. Hal tersebut terjadi karena akun media sosial ZAP yang paling aktif adalah Instagram dan saat ini Instagram menjadi salah satu platform media sosial favorit bagi masyarakat Indonesia, terutama generasi milenial. Selain itu, rata-rata responden di seluruh kategori usia menggunakan media sosial terutama Instagram pada pukul pada pukul $18.00-21.00$. Waktu sore hingga malam dirasa tepat bagi mayoritas responden untuk menggunakan media sosial karena waktu tersebut adalah kegiatan sehari-harinya seperti kuliah dan bekerja telah selesai. Namun, terdapat cukup banyak responden yang berusia 24 hingga 30 tahun menggunakan media sosial pada pukul $12.00-15.00$ yang menggambarkan bahwa responden menggunakan media sosial di waktu senggang seperti saat istirahat siang. Sedangkan responden yang sering mengunjungi akun Facebook dan YouTube, waktu penggunaan media sosial juga beragam mulai dari pagi hingga malam hari. Hasil analisis crosstab ini menunjukkan bahwa sore hingga malam hari merupakan waktu yang tepat bagi ZAP Clinic untuk mengunggah konten atau update di media sosialnya, karena mayoritas pengikutnya menggunakan media sosial pada waktu tersebut. 
Crosstab 5 - Analisis crosstab kelima memberikan informasi mengenai hubungan antara usia, bentuk konten media sosial yang paling digemari, dan konten media sosial ZAP yang paling digemari. Hasil analisis crosstab kelima menunjukkan bahwa mayoritas responden dari usia 19 hingga 50 tahun menyukai konten media sosial berbentuk video. Baik responden yang menyukai konten berbentuk foto, konten grafis, dan video menyukai konten media sosial yang berisi tentang informasi terkait ZAP Clinic seperti kegiatan yang dilakukan ZAP, perawatan dan produk baru, dan lainnya. Mayoritas responden menyukai konten berbentuk video karena ZAP Clinic menawarkan layanan, dimana layanan yang ditawarkan akan terlihat lebih jelas melalui video. Responden yang berusia 24 hingga 30 tahun cukup banyak yang menyukai konten berbentuk foto, dimana konten foto ZAP Clinic banyak yang merupakan review atau testimoni pelanggan ZAP Clinic. Hal tersebut dapat meningkatkan kepercayaan pengikut media sosial ZAP terhadap layanan yang ditawarkan, karena testimoni langsung berasal dari pelanggan ZAP. Bagi responden yang menyukai konten berisi kuis atau giveaway, kelompok responden tersebut lebih menyukai konten berbentuk grafis. Hal tersebut dikarenakan unggahan terkait kuis atau giveaway lebih menarik dalam bentuk poster dengan desain menarik dan informasi yang singkat namun jelas. Dengan menggunakan poster atau konten grafis, konten tersebut dapat dicari dengan mudah karena visualisasi yang berbeda dengan foto maupun video.

\section{Analisis CLI}

Penelitian ini melakukan analisis Customer Loyalty Index (CLI) untuk mengetahui seberapa besar tingkat loyalitas pelanggan terhadap ZAP Clinic. Dalam analisis CLI, langkah pertama adalah menghitung performance atau mean dari masing-masing atribut loyalitas yang disebut dengan willing statement. Penelitian ini menggunakan enam atribut untuk mengukur loyalitas pelanggan, dimana masing-masing atribut tersebut memiliki nilai willing statement yang kemudian dibagi dengan nilai skala likert tertinggi yaitu 7 dan kemudian dikalikan dengan 100 persen. Kemudian dari keempat nilai willingness statement tersebut akan dicari rataratanya untuk mendapatkan nilai CLI secara kesuluruhan. Berikut adalah tingkat loyalitas pelanggan ZAP Clinic (Tabel 3).

Nilai Customer Loyalty Index (CLI) ZAP Clinic yang diperoleh adalah sebesar 88,95 persen berada pada rentang 71-90 persen yang dapat diinterpretrasikan bahwa pelanggan ZAP Clinic saat ini termasuk loyal. Semua indikator CLI menunjukkan indeks yang tinggi, dengan indikator LM5 memiliki indeks paling tinggi yang menunjukkan bahwa pelanggan merasa puas setiap kali berkunjung ke ZAP Clinic baik untuk membeli sesuatu, melakukan treatment, atau hanya sekedar mencari informasi. Hal tersebut menggambarkan bahwa apa yang dilakukan ZAP Clinic saat ini dapat membuat pelanggan merasa puas dan loyal. Sedangkan indeks terendah dimiliki indikator LM4 yaitu niat untuk berkunjung kembali. Hasil tersebut menunjukkan meskipun pelanggan merasa puas setiap kali berkunjung ke ZAP Clinic, namun niat untuk berkunjung kembalinya lebih rendah.

Untuk menjaga loyalitas pelanggan, saat ini ZAP Clinic memiliki dua program loyalitas yaitu pengumpulan poin yang dapat ditebus untuk pembelian perawatan kecantikan. Namun program loyalitas poin di ZAP Clinic kurang disosialisasikan,
Tabel 3.

Customer Loyalty Index (CLI) ZAP Clinic

\begin{tabular}{llcc}
\hline \hline Kode & \multicolumn{1}{c}{ Indikator Loyalitas } & Willing Statement & CLI (\%) \\
\hline LM1 & $\begin{array}{l}\text { Menyarankan kepada orang } \\
\text { lain }\end{array}$ & 6,29 & 89,80 \\
LM2 & $\begin{array}{l}\text { Merekomendasikan kepada } \\
\text { teman }\end{array}$ & 6,29 & 89,80 \\
LM3 & Mengunjungi dengan teratur & 6,17 & 88,10 \\
LM4 & Niat untuk berkunjung kembali & 5,93 & 84,76 \\
LM5 & Puas setiap kali berkunjung & 6,50 & 92,79 \\
LM6 & Pilihan pertama & 6,19 & 88,44 \\
Total & & & 88,95 \\
\hline \hline
\end{tabular}

sehingga pelanggan masih jarang yang menyadari adanya ZAP Point. Selain itu, ZAP Point tidak bisa ditebus untuk perawatan di ZAP Premiere dan pembelian produk ZAP. Selain itu ZAP memiliki program loyalitas berbayar bernama hair removal membership untuk pelanggan yang melakukan perawatan hair removal. Sedangkan berdasarkan analisis usage, perawatan photo facial merupakan perawatan yang paling favorit di antara pelanggan ZAP Clinic saat ini. Oleh karena itu, ZAP Clinic dapat melakukan beberapa strategi agar loyalitas pelanggan tetap terjaga dan tidak mudah beralih pada klinik kecantikan lain, bahkan dapat meningkat hingga sangat loyal.

\section{B. Implikasi Manajerial}

Berikut adalah implikasi manajerial yang berguna bagi pemasar dan ZAP Clinic berdasarkan analisis crosstab dan CLI.

1. Implikasi Manajerial Berdasarkan Perilaku Pelanggan

Sebagian besar responden merupakan wanita milenial yang bekerja. Kelompok responden tersebut rela mengeluarkan uang sebesar Rp 500.001 hingga Rp 1.000.000 dalam satu kali kunjungan di ZAP Clinic. Selain itu, mayoritas responden menggemari perawatan photo facial dan banyak perawatan kecantikan yang kurang digemari, terutama perawatan untuk badan. Oleh karena itu, ZAP Clinic dapat memberikan edukasi terkait pentingnya merawat diri secara keseluruhan, mulai dari badan, wajah, hingga kulit kepala, terlebih ZAP Clinic menggunakan alat yang canggih dan berstandar internasional. Edukasi tersebut dapat disampaikan saat konsumen melakukan konsultasi dengan dokter, saat menjalankan perawatan kecantikan dengan dokter atau beauty therapist, saat check out, dan disampaikan melalui media sosial. Hal tersebut juga berguna untuk memberikan kesan yang baik pada konsumen. Selain itu, ZAP Clinic dapat menawarkan paket perawatan untuk badan dan wajah dengan harga yang lebih terjangkau dibandingkan dengan membeli satuan.

Mayoritas responden melakukan perawatan kecantikan di ZAP Clinic sebanyak empat kali atau lebih. Hal tersebut menunjukkan bahwa responden cukup rutin melakukan perawatan kecantikan. Maka dari itu, ZAP Clinic dapat memberikan reward berupa potongan harga untuk pembelian produk atau perawatan kecantikan pada transaksi selanjutnya. Dengan cara tersebut, konsumen akan lebih terdorong untuk melakukan pembelian di masa mendatang sebagai salah satu bentuk loyalitas kepada ZAP Clinic.

Analisis penggunaan media sosial menunjukkan perbandingan responden yang mengikuti media sosial Instagram dengan media sosial lainnya (Facebook, YouTube, dan LINE@) cukup jauh, dengan mayoritas responden paling 
sering mengunjungi akun media sosial Instagram. Selain itu, rata-rata responden di seluruh kategori usia menggunakan media sosial terutama Instagram pada pukul pada pukul $18.00-21.00$.

Maka dari itu, selain tetap aktif melakukan pemasaran di platform Instagram, ZAP Clinic perlu lebih aktif membagikan konten dan berinteraksi pada platform media sosial lainnya untuk menjangkau calon konsumen lebih luas. ZAP Clinic juga dapat menggunakan fitur Facebook $A d s$ untuk menjangkau konsumen lebih banyak, mengingat sebagian besar pengguna media sosial di Indonesia menggunakan Facebook [18]. Selain itu, ZAP Clinic lebih baik mengunggah konten di media sosial pukul 18.00 hingga 21.00. ZAP Clinic juga dapat mengadakan kuis atau game berhadiah pada jam tersebut untuk meningkatkan interakasi dengan pengikut media sosialnya.

Mayoritas responden dari seluruh kategori usia menyukai konten media sosial berbentuk video. Baik responden yang menyukai konten berbentuk foto, konten grafis, dan video menyukai konten media sosial yang berisi tentang informasi terkait ZAP Clinic seperti kegiatan yang dilakukan ZAP, perawatan dan produk baru, dan lainnya. Agar terlihat menarik dan tidak membosankan, ZAP Clinic perlu mengunggah konten berisi informasi tentang ZAP Clinic dengan cara yang berbeda seperti membuat series "ZAP Talks" yang akan membahas topik tertentu dan rutin dilakukan setiap minggu. Untuk mendapatkan topik ZAP Talks, ZAP Clinic dapat bertanya kepada pengikut media sosialnya dengan memanfaatkan fitur polling yang tersedia pada platform Instagram, Twitter, Facebook, dan LINE@. Selain polling, Facebook memiliki fitur "reaksi" dimana pengguna dapat memberikan reaksi love, haha, wow, sedih, dan marah yang dapat dimanfaatkan ZAP Clinic untuk mengetahui minat atau reaksi penngikut tentang topik tertentu. Dengan begitu, ZAP Clinic dapat membahas topik tertentu berdasarkan keinginan pengikutnya. Selain itu, ZAP Clinic juga dapat mengunggah lebih banyak konten berbentuk video seperti vlog dan web series.

2. Implikasi untuk Mempertahankan dan Meningkatkan Loyalitas Pelanggan

Berdasarkan hasil analisis CLI, pelanggan ZAP Clinic saat ini berada pada tahap loyal kepada ZAP Clinic. Untuk mempertahankan dan meningkatkan loyalitas pelanggan, ZAP Clinic dapat memberikan manfaat kepercayaan, manfaat sosial, dan manfaat special treatment bagi pelanggannya [19]. ZAP Clinic dapat memberikan manfaat kepercayaan dengan menjaga kualitas layanan saat ini misalnya dokter dan beauty therapist yang menggunakan masker dan sarung tangan untuk menjaga kebersihan, sehingga pelanggan tidak cemas dan memiliki kepercayaan tinggi terhadap kinerja ZAP Clinic. Untuk memberikan manfaat sosial, personel ZAP Clinic termasuk front liner, apoteker, beauty therapist dan dokter harus menciptakan suasana yang nyaman dan friendly seperti mengenali nama pelanggan dan memberikan greeting sebelum dan setelah pelanggan melakukan perawatan kecantikan. Untuk memberikan manfaat special treatment atau reward non-finansial, ZAP Clinic dapat memberikan diskon atau penawaran khusus bagi pelanggan yang loyal, memprioritaskan pelanggan yang loyal untuk dapat melakukan reservasi perawatan kecantikan (antrian virtual). Pelanggan yang loyal dapat diketahui dari yang telah membeli series atau ZAP gift card yang menandakan pelanggan tersebut memiliki saldo.

Selain memberikan manfaat, ZAP Clinic dapat meningkatkan loyalitas pelanggan memberikan reward loyalitas finansial dan non-finansial [19]. Saat ini ZAP Clinic telah memiliki program loyalitas ZAP Point, namun kurang disosialisasikan, sehingga ZAP Clinic perlu melakukan sosialisasi tentang manfaat yang bisa didapatkan pelanggan jika mengumpulkan poin dan memberikan informasi jumlah poin yang didapatkan saat pelanggan melakukan check out. Selain itu, ZAP Clinic sebaiknya menambahkan layanan yang dapat ditebus dengan ZAP Point, yaitu layanan di ZAP Premiere sehingga pelanggan tergerak untuk mengumpulkan poin lebih banyak. ZAP Clinic juga melakukan program cashback yang disediakan berbagai penerbit kartu kredit.

\section{V.SIMPULAN DAN SARAN}

\section{A. Simpulan}

Indeks loyalitas menunjukkan bahwa pelanggan ZAP Clinic berada pada tingkat loyal, dimana pelanggan berkeinginan untuk merekomendasikan ZAP Clinic kepada orang lain termasuk orang-orang terdekatnya. Pelanggan juga teratur mengunjungi ZAP Clinic untuk melakukan perawatan kecantikan dan akan kembali di lain waktu. Selain merasa puas setiap kali mendapatkan layanan perawatan kecantikan, ternyata ZAP Clinic akan menjadi pilihan pertama pelanggan. Untuk menjaga loyalitas pelanggan, ZAP Clinic dapat melakukan beberapa strategi seperti menjaga kualitas layanan, menciptakan suasana yang nyaman, dan memberikan perlakuan khusus agar pelanggan merasa spesial. Selain itu, ZAP Clinic dapat melakukan sosialisasi agar pelanggan aware akan ZAP Point dan mengadakan program cashback dengan bekerja sama dengan penyedia kartu kredit.

\section{B. Saran}

Penelitian selanjutnya dapat mempertimbangkan untuk memperluas cakupan penelitian yaitu media sosial klinik kecantikan lainnya, karena saat ini terdapat banyak klinik kecantikan yang melakukan pemasaran melalui media sosial. Selain itu juga untuk memperluas sampel dengan mengikutsertakan laki-laki karena sebagian laki-laki di Indonesia turut melakukan perawatan kecantikan, sehingga didapatkan sudut pandang yang berbeda. Diversifikasi usia responden juga perlu dilakukan dengan memperbanyak responden yang berusia lebih dewasa atau generasi X, sehingga lebih merepresentasikan pelanggan klinik kecantikan di Indoensia saat ini. Penelitian selanjutnya dapat membedakan pelanggan yang mengikuti media sosial merek tertentu berdasarkan tingkat keaktifan dalam menggunakan media sosial dan tingkat interaksinya dengan media sosial merek tertentu. Sehingga, dapat terlihat perbedaan perilaku pada kategori responden yang berbeda. Dalam pembuatan kuesioner, penelitian selanjutnya dapat melakukan analisis terlebih dahulu terkait struktur kalimat yang digunakan, sehingga data yang yang diperoleh sesuai dengan keadaan sebenarnya. Sedangkan untuk merekomendasikan implikasi manajerial, penelitian selanjutnya dapat melakukan validasi terlebih dahulu kepada perusahaan terkait. 


\section{DAFTAR PUSTAKA}

[1] Metro TV News, "Mikro | 2020, Industri Kecantikan RI Siap Libas Asia Tenggara," $2017 . \quad$ [Online]. Available: http://ekonomi.metrotvnews.com/read/2017/04/29/693179/2020industri-kecantikan-ri-siap-libas-asia-tenggara. [Accessed: 16-Sep2018].

[2] L'Oréal, "Pertumbuhan L'Oréal Indonesia Lampaui Pasar Dalam Satu Dekade Terakhir," $2017 . \quad$ [Online]. Available: https://www.loreal.co.id/berita/pertumbuhan-loreal-indonesia-lampauipasar-dalam-satu-dekade-terakhir-6329.htm. [Accessed: 12-Oct-2018].

[3] KOMPAS.com, "Cerahnya Bisnis Klinik Kecantikan di Tahun 2018," 2018. [Online]. Available: https://amp.kompas.com/lifestyle/read/2018/01/11/183119020/cerahny a-bisnis-klinik-kecantikan-di-tahun-2018.

[4] Markplus.inc, "Zap Beauty Index 2018," 2018.

[5] Marketeers, "Mengintip Geliat Industri Kecantikan di Era Digital Marketeers - Majalah Bisnis \&amp; Marketing Online Marketeers.com," 2017. [Online]. Available: http://marketeers.com/mengintip-geliat-industri-kecantikan-di-eradigital/. [Accessed: 16-Sep-2018].

[6] Bisnis Indonesia, "ZAP Clinic Raih Top Brand Award 2018," 2018. [Online]. Available: http://industri.bisnis.com/read/20180802/12/823496/zap-clinic-raihtop-brand-award-2018. [Accessed: 16-Sep-2018].

[7] Marketing.co.id, "Top Brand 2018," 2018. [Online]. Available: https://marketing.co.id/lagi-zap-clinic-raih-top-brand-award-2018/. [Accessed: 14-Oct-2018].

[8] E. Seo and J. Park, "Journal of Air Transport Management A study on the effects of social media marketing activities on brand equity and customer response in the airline industry," J. Air Transp. Manag., vol. 66, no. September 2017, pp. 36-41, 2018.
[9] B. Godey et al., "Social media marketing efforts of luxury brands: Influence on brand equity and consumer behavior," J. Bus. Res., 2016.

[10] P. Kotler, H. Kartajaya, and I. Setiawan, Marketing 4.0: Moving From Traditional to Digital. New Jersey: John Wiley \& Sons, Inc., 2017.

[11] P. Kotler and K. L. Keller, A Framework for Marketing Management, 6th ed. Harlow: Pearson Education Limited, 2016.

[12] K. L. Keller, Strategic Brand Management, 4th ed. Harlow: Pearson Education Limited, 2013.

[13] R. G. Netemeyer et al., "Developing and validating measures of facets of customer-based brand equity," J. Bus. Res., vol. 57, no. 2, pp. 209224, 2004.

[14] M. R. Solomon, G. Bamossy, S. Askegaard, and M. K. Hogg, Consumer Behaviour. 2006.

[15] N. K. Malhotra, Marketing Reasearch: an Applied Orientation, 6th ed. New Jersey: Pearson Education Inc., 2010.

[16] J. F. Hair, W. C. Black, B. J. Babin, and R. E. Anderson, "Multivariate Data Analysis," Vectors. p. 816, 2010.

[17] A. S. Wibowo, H. K. Suwarsinah, and L. N. Yuliati, "The Effects of PVTI's Corporate Image and Service Quality on Satisfaction and Loyalty of The KSO SCISI Customers," Indones. J. Bus. Entrep., vol. 4, no. 1, pp. 75-87, 2018.

[18] Kominfo, "Angka Penggunaan Media Sosial Orang Indonesia Tinggi, Potensi Konflik juga Amat Besar," 2018. [Online]. Available: https://kominfo.go.id/content/detail/14136/angka-penggunaan-mediasosial-orang-indonesia-tinggi-potensi-konflik-juga-amatbesar/0/sorotan media. [Accessed: 12-Jan-2019].

[19] J. Wirtz and C. Lovelock, Services Marketing: People, Technology, Strategy, 8th ed. Pearson Education Inc., 2016.

[20] S. N. Husin and B. M. Wibawa, "Identifikasi Perilaku Konsumen Online Ride Sharing: Studi Kasus Go-Jek dan Grab," J. Tek. ITS, pp. $1-4$. 